\title{
Occurrence and distribution patterns of several marine vertebrates in Golfo Dulce, Costa Rica
}

\author{
Brooke L. Bessesen ${ }^{1}$ \\ Joyce Corrigan Memorial Care Center, Phoenix Zoo, Phoenix, Arizona, 85008, United States of America; \\ brooke@brookebessesen.com
}

Received 11-VIII-2014. Corrected 20-XI-2014. Accepted 22-XII-2014.

\begin{abstract}
Within the months of January-February 2010 and July-August 2011, 55 daily sighting surveys were conducted in Golfo Dulce, a tropical fiord-like embayment in the South Pacific region of Costa Rica. The research objective was to collect baseline data on several marine vertebrates that enter or reside in the Gulf and determine spatial distribution during the study periods. Sighting surveys mainly focused on whales, dolphins, sea turtles and sea snakes. A total of 458 recorded sightings, representing at least 30 marine species, were acquired during 423.7 observation hours across all areas of the embayment. These data, along with information garnered from 82 interviews with local fishermen and tour boat guides, confirmed a wide array of marine species utilizing the inlet for the purposes of foraging, mating, resting and socializing. GIS analyses allowed comparisons of spatial distribution and revealed high-density areas for marine fauna within Golfo Dulce. Rev. Biol. Trop. 63 (Suppl. 1): 261-272. Epub 2015 April 01.
\end{abstract}

Key words: marine vertebrates, spatial distribution, fiord habitat, Costa Rica, conservation, Eastern Tropical Pacific.

Golfo Dulce, located along the South Pacific coastline of Costa Rica, is an embayment with fiord-like characteristics rare to the tropics (Wolff, Hartman \& Koch, 1996). The upper region of the inlet is characterized by a deep inner basin of tectonic origin more than 200m deep (Hebbeln \& Cortés, 2001), separated by an effective sill and supplied with fresh water from several rivers and tributaries (Svendsen et al., 2006). These bathymetrics and hydrography make Golfo Dulce a distinctive aquatic habitat of emerging biological interest that supports an impressive variety of at least 1028 species (Morales-Ramírez, 2011). The largest and most mobile vertebrates utilizing the habitat are the cetaceans. Megaptera novaeangliae (Borowski, 1781) annually migrates from colder feeding grounds to warmer breeding/calving grounds, and the waters surrounding the Osa Peninsula are distinguished for a geographical overlap of whales from both hemispheres (Acevedo \& Smultea, 1995; Rasmussen et al., 2007; Oviedo \& Solís, 2008). The North Pacific population arrives in the Eastern Tropical Pacific (ETP) during the boreal winter (December-March, Costa Rican dry season) and the Southern Hemisphere population arrives in the ETP during austral winter (July-October, Costa Rican rainy season). Tursiops truncatus (Montagu, 1821) and Stenella attenuata (Gray, 1846) reside sympatrically within the embayment (AcevedoGutiérrez \& Burkhart, 1998; Cubero-Pardo, 2007; Oviedo, 2007) although other delphinids, including Pseudorca crassidens (Owen, 1846) occasionally enter the habitat (Acevedo-Gutierrez, Brennan, Rodriguez \& Thomas, 1997). Sea turtles, Chelonia mydas (Linnaeus, 1758), Lepidochelys olivacea (Eschscholtz, 1829), Eretmochelys imbricata (Linnaeus, 1766), and Dermochelys coriacea (Vandelli, 1761) have been reported around the Osa Peninsula 
(Quesada-Alpízar, Cortés-Núñez, Alvarado \& Fonseca, 2006). The first three have been documented inside Golfo Dulce, including a sizeable population of $C$. mydas resting, feeding and breeding in the northern reaches of the inlet (Bessesen \& Saborío, 2012). Pelamis platura (Linnaeus, 1766) is the only sea snake found on the Pacific side of Costa Rica (Solórzano, 2004). While this venomous serpent typically displays some variation of black dorsal coloration with yellow-brown ventrolateral surfaces and black posterior spots or bands, a residential colony of xanthic (all-yellow or predominantly yellow) P. platura has recently been described inside Golfo Dulce (Solórzano, 2011; Bessesen, 2012). The embayment also appears to be critical reproductive habitat for sharks, including Sphyrna lewini (Griffith \& Smith, 1834) (López-Garro, 2012).

Fishing is central to life around Golfo Dulce. Artisanal and small commercial boats generally work inside the embayment and daily sport fishing vessels ferry tourists to the open Pacific where they can capture larger prey. In 2010 and 2011, on-water sighting surveys were undertaken and interviews with local fishermen and tour boat guides were conducted to collect baseline data on a range of marine vertebrates that utilize Golfo Dulce as part of their natural ecology. The breadth of our findings is presented here; some previously published data (Bessesen, 2012; Bessesen \& Saborío, 2012; Bessesen et al., 2014) are included to provide a comprehensive and comparative view. Distribution patterns in particular should serve to stress the importance of maintaining Golfo Dulce in healthy condition.

\section{MATERIALS AND METHODS}

Study site: Golfo Dulce ( $8^{\circ} 44^{\prime} 48^{\prime \prime}$ $8^{\circ} 21^{\prime} 57^{\prime \prime} \mathrm{N}-83^{\circ} 29^{\prime} 5^{\prime \prime}-83^{\circ} 5^{\prime} 33^{\prime \prime} \mathrm{W}$ ) is a curved embayment approximately $50 \mathrm{~km}$ in length and $10-15 \mathrm{~km}$ wide (Svendsen et al., 2006). An inner basin of tectonic origin (Hebbeln \& Cortés, 2001), which reaches $215 \mathrm{~m}$ in depth, is separated from adjacent coastal water masses by an effective sill and a shallow outer basin that is $60-80 \mathrm{~m}$ deep. Freshwater is dispensed from four major rivers, Rincón, Esquinas, Tigre and Coto Colorado and several smaller tributaries (Svendsen et al., 2006). In riparian zones, dense mangroves dominate the shoreline topography, while other areas feature coral reefs and sandy beaches (Wolff et al., 1996). For surveys, the Gulf was divided into four geographical areas (quadrants), GA1-4, highest to lowest latitudes, respectively. GA1 and GA4 were designed smaller to account for distance from the operations base of Puerto Jiménez and additional time spent in GA2 and GA3 as corridors (Fig. 1).

Field Procedures: Surveys were conducted from 13 January to 24 February 2010 (dry season) and 7 July to 25 August 2011 (rainy season) using a 3-6m panga with a $15-50 \mathrm{hp}$ engine. At least two experienced observers were aboard the research vessel at all times. One area was traversed each day, employing a general rotation of GA1, GA3, GA2, GA4. A large, variable travel pattern, i.e., figure-eight, zigzag, always ensured time near each coast and in the midwaters. Daily travel distance ranged from $65-80 \mathrm{~km}$. The area outside the embayment, labeled GA5, was not actively surveyed, although occasional sightings were made in that area while working along the border of GA4/GA5. Environmental conditions were logged at the start and end of each onboard period, including air and sea surface temperatures, visibility $(1+, 15+, 25+\mathrm{km})$ and Beauford Wind Force (BWF; Table 1).

Sighting data: The surveys focused on target taxa: whales, dolphins, sea turtles and sea snakes; however, additional sightings deemed significant were also recorded, no matter the species. The sighting time was recorded as soon as the animal(s) were in view. Duration of sighting was not measured. Sighting locations were recorded using Global Satellite Positioning (GPS) so GIS maps could then be created. Biological data included species, distinctive markings (used to identify individuals when possible), presence of offspring 
TABLE 1

Summary of environmental data collected at start and finish of each daily survey period

\begin{tabular}{lccccc}
\multicolumn{1}{c}{ Variable } & Minimum & Maximum & Average & $\begin{array}{c}\text { Average Dry season } \\
\text { (Jan-Feb 2010) }\end{array}$ & $\begin{array}{c}\text { Average Rainy season } \\
\text { (July-Aug 2011) }\end{array}$ \\
Air Temperature $\left({ }^{\circ} \mathrm{C}\right)$ & 23.5 & 35 & 28.1 & 28.6 & 27.5 \\
Sea Surface Temperature $\left({ }^{\circ} \mathrm{C}\right)$ & 26.5 & 32.5 & 29.8 & 30.5 & 29 \\
Visibility (km) & $1+$ & $25+$ & $15+$ & $15+$ & $15+$ \\
Beauford Wind Force & 0 & 4 & 1.84 & 2.1 & 1.5 \\
Observation period $(\mathrm{hrs})$ & 3.7 & 9.3 & 7.7 & 7.7 & 7.8 \\
\hline
\end{tabular}

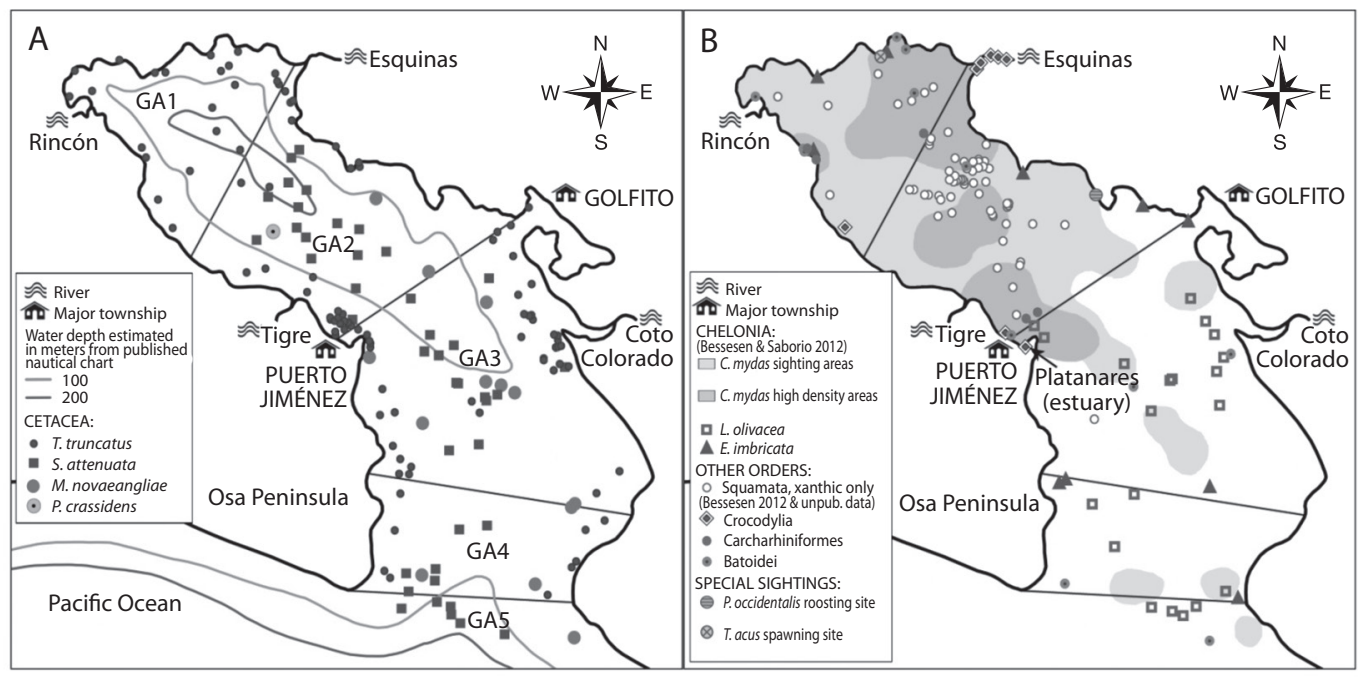

Fig. 1. Location of sighting points for several marine vertebrates observed at Golfo Dulce, divided by geographical area (GA1-5). (A) Cetaceans; (B) Chelonids and other taxa. The Pseudorca sighting and the crocodylia sighting south of Puerto Jiménez were off-survey. Some orders/species sighted during the surveys are not included. Note high-use area for cetaceans and chelonids off Puerto Jiménez.

when applicable, and behavior. Species ID reliability was logged as definite (D), probable $(\mathrm{P})$, maybe $(\mathrm{M})$ or unconfirmed (U). Those marked $\mathrm{M}$ or $\mathrm{U}$ for target taxa were excluded from this reporting, so certain numbers may be less than the full count. A sighting included all individuals of the same species in the same area at the same time; therefore, one sighting could represent multiple animals. The number of individuals was recorded for each sighting. When the exact number was unclear, three estimates were logged: 1) minimum count, 2) maximum count and 3) best estimated count. The final number of sighted individuals presented for each species is simply a cumulative total; when an exact figure could not be calculated, the most conservative figure (sum of "minimum counts") was used and identified as an estimate. Multiple sightings of particular individuals did occur.

Interviews: Interviews were conducted with 82 local artisanal and tourism-sport fishermen and tour boat guides. Each defined their marine work experience in Golfo Dulce: type of work, days per week and number of years. They were then asked to estimate the frequency of their observations for the target taxa, choosing among the following options: always, frequently, occasionally, rarely, or never. A photographic guide was made available and responses were recorded onto paper 
interview forms, which included space for additional remarks. A full-house meeting of fishermen's associations was attended in Golfito on 14 January 2010 to investigate the interests and concerns of the community relating to Golfo Dulce.

\section{RESULTS}

Air temperature and sea surface temperatures taken at the marina near Puerto Jiménez averaged $28.1^{\circ} \mathrm{C}$ and $29.8^{\circ} \mathrm{C}$, respectively. Average visibility was greater than $15 \mathrm{~km}$. BWF averaged $<2$ (smooth wavelets, $<0.1 \mathrm{~m}$ ), although on two occasions it did briefly reach as high as 4 (small wavecaps, $0.5-1.2 \mathrm{~m}$ ). Daily observation periods lasted $7 \mathrm{hr}$ and $46 \mathrm{~min}$ on average (Table 1). A total of $423.7 \mathrm{~h}$ of observation over 55 survey days rendered 458 recorded sightings. Sightings divided by geographical area show overall densities: $21 \%$ occurred in GA1, representing $>362$ individuals; $42 \%$ of sightings occurred in GA2, representing $>1634$ individuals; $23 \%$ occurred in GA3, representing $>672$ individuals; $13 \%$ occurred in GA4, representing $>246$ individuals; the remaining $1 \%$ occurred in GA5, representing $>28$ individuals. More than 30 marine species were recorded during the study (Figs. 1 and 2, Table 2 ) and the majority of sightings (78\%) was photographically documented.

Sightings of target taxa: Four species of the order Cetacea were seen in Golfo Dulce. WHALES. M. novaeangliae were recorded at 13 sightings, representing 25 whales (15 adults, 10 calves). Individuals were recorded during both the dry $(\mathrm{N}=5)$ and rainy $(\mathrm{N}=20)$ seasons (Fig. 3), predominantly $(\mathrm{N}=13)$ in the more shallow outer basin waters of GA3. One mother-calf pair was sighted shortly after sunrise near the beachline in a calm bay just south of Puerto Jiménez; the calf appeared to be a neonate with dorsal fin still creased and furled as described by Cartwright and Sullivan (2009). The pair remained tightly together in the area, surfacing frequently. Another mother-calf pair displayed nursing behavior; the

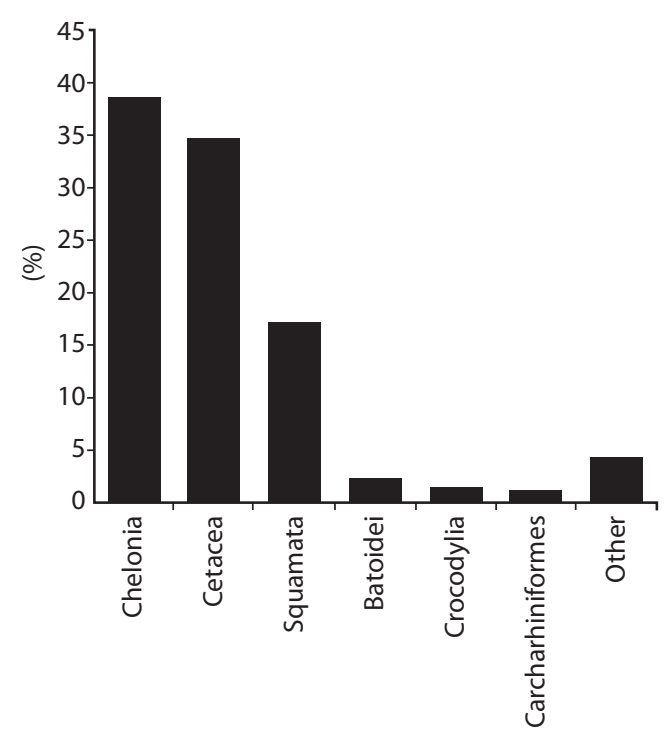

Fig. 2. Percentage of total sightings by taxa.

mother was found resting quietly at the surface while the calf fed and photographs confirmed plumes of milk in the water (Fig. 3B). Other humpback behaviors included traveling, milling, breaching and long localized dive cycles. DOLPHINS. A total of 141 dolphin sightings were recorded with the majority $(\mathrm{N}=98)$ occurring in GA2-GA3. T. truncatus was recorded at 98 sightings, representing an estimated 400 dolphins. Sixty-eight individual bottlenose were photo-identified using dorsal fin profiling described by Würsig and Jefferson (1990); several exhibited chronic dermal lesions identified as lacaziosis-like disease (Bessesen et al., 2014). S. attenuata was recorded at 42 sightings, representing approximately 1574 dolphins. Habitat partitioning as described by Acevedo-Gutiérrez and Burkhart (1998), Cubero-Pardo (2007) and Oviedo (2007) was evident between these resident delphinids; $T$. truncatus, found in all quadrants, tended to be coastally aligned with sighting densities near the large river outlets, while $S$. attenuata, often observed in larger fission-fusion grouping patterns, was found in central waters from GA2GA5, but not in GA1. Both species were seen foraging, traveling, and socializing with calves 
TABLE 2

Sighting data for vertebrate taxa observed in the different sectors of Golfo Dulce

\begin{tabular}{|c|c|c|c|c|c|c|}
\hline \multirow[b]{3}{*}{ Location } & \multicolumn{5}{|c|}{ Geographical areas } & \\
\hline & GA1 & GA2 & GA3 & GA4 & GA5 & \\
\hline & highest sector & mid-upper & mid-lower & lowest sector & outside gulf & \\
\hline Estimated surface size & $130 \mathrm{~km}^{2}$ & $192 \mathrm{~km}^{2}$ & $256 \mathrm{~km}^{2}$ & $147 \mathrm{~km}^{2}$ & - & \\
\hline Number of survey days & 13.75 & 14.25 & 13.75 & 13.25 & - & \\
\hline Approximate survey hours & 97.75 & 116.83 & 118.5 & 88.83 & 1.75 & \\
\hline \# sightings/individuals: & & & & & & Totals: \\
\hline CETACEA & $22 />110^{1}$ & $46 />1306$ & $61 />512$ & $18 />76$ & $7 />22$ & $154 />2026$ \\
\hline Megaptera novaeangliae & 0 & $2 / 4$ & $7 / 13$ & $3 / 5$ & $1 / 3$ & $13 / 25$ \\
\hline Tursiops truncatus & $22 />110$ & $27 />110$ & $40 />154$ & $9 / 25$ & - & $98 />399$ \\
\hline Stenella attenuata & 0 & $16 />1164$ & $14 />345$ & $6 />46$ & $6 />19$ & $42 />1574$ \\
\hline Pseudorca crassidens ${ }^{2}$ & 0 & $1 />28$ & 0 & 0 & - & $1 />28$ \\
\hline CHELONIA & $42 />217$ & $50 / 59$ & $24 / 27$ & $10 / 11$ & $5 / 5$ & $131 />319$ \\
\hline Chelonia mydas & $39 />214$ & $48 / 57$ & $10 / 12$ & $3 / 4$ & $1 / 1$ & $101 />288$ \\
\hline Lepidochelys olivacea & 0 & 0 & $12 / 13$ & $4 / 4$ & $4 / 4$ & $20 / 21$ \\
\hline Eretmochelys imbricata & $3 / 3$ & $2 / 2$ & $2 / 2$ & $3 / 3$ & - & $10 / 10$ \\
\hline SQUAMATA & $8 / 8$ & $57 / 59$ & $1 / 1$ & 0 & - & $66 / 68$ \\
\hline Pelamis platurus ${ }^{3}$ & $8 / 8$ & $57 / 59$ & $1 / 1$ & 0 & - & $66 / 68$ \\
\hline CROCODYLIA & $1 / 1$ & $6 / 6$ & $1 / 4$ & 0 & - & $8 / 11$ \\
\hline Crocodylus acutus & $1 / 1$ & $6 / 6$ & 0 & 0 & - & $7 / 7$ \\
\hline Caiman crocodilus ${ }^{4}$ & 0 & 0 & $1 / 4$ & 0 & - & $1 / 4$ \\
\hline CARCHARHINIFORMES & $3 / 3$ & $2 / 2$ & 0 & 0 & - & $5 / 5$ \\
\hline Galeocerdo cuvier & $1 / 1$ & $1 / 1$ & 0 & 0 & - & $2 / 2$ \\
\hline Carcharhinus leucas & $1 / 1$ & 0 & 0 & 0 & - & $1 / 1$ \\
\hline Sphyrna lewini & $1 / 1$ & 0 & 0 & 0 & - & $1 / 1$ \\
\hline shark, spp. unconfirmed & 0 & $1 / 1$ & 0 & 0 & - & $1 / 1$ \\
\hline BATOIDEI & $6 / 11$ & $2 / 2$ & $2 / 4$ & $1 / 1$ & $1 / 1$ & $12 / 19$ \\
\hline Manta spp. & 0 & $1 / 1$ & $1 / 3$ & $1 / 1$ & - & $3 / 5$ \\
\hline Aetobatus spp. & $2 / 3$ & $1 / 1$ & $1 / 1$ & 0 & $1 / 1$ & $5 / 6$ \\
\hline Rhinoptera spp. & $1 / 4$ & 0 & 0 & 0 & - & $1 / 4$ \\
\hline Dasyatis spp. & $3 / 4$ & 0 & 0 & 0 & - & $3 / 4$ \\
\hline OTHER SELECTED SPECIES ${ }^{5}$ & $1 />1$ & $2 />182$ & 0 & 0 & - & $3 />183$ \\
\hline Pelecanus occidentalis & 0 & $2 />182$ & 0 & 0 & - & $2 />182$ \\
\hline Tylosurus acus pacificus & $1 />1$ & 0 & 0 & 0 & - & $1 />1$ \\
\hline Totals by geographical area & $83 />351$ & $165 />1616$ & $89 />548$ & $29 />88$ & $13 />28$ & $379 />2631$ \\
\hline
\end{tabular}

1. represents minimum estimated counts.

2. within survey period, sighted from the research vessel of Centro de Investigación de Cetáceos.

3. data for xanthic snakes only=all-yellow coloration (Bessesen, 2012, unpublished).

4. within survey period, sighted during a kayak trip into the estuary near Puerto Jiménez called Platanares.

5. not all orders/species seen during surveys are included in this table.

occasionally present. One other species of cetacean was sighted in Golfo Dulce while aboard the research vessel of Centro de Investigación de Cetáceos (CEIC, previously Project Golfo Dulce Wildlife): a group of approximately 30 P. crassidens in GA2 (Figs. 1A and 2). SEA TURTLES. Three species of the order Chelonia were documented in the study area. C. mydas was recorded at 101 sightings from GA1-GA5, representing approximately 300 sea turtles, including 7 copulating pairs. The majority of
C. mydas sightings $(\mathrm{N}=87)$ occurred in high density areas in the upper Gulf where the turtles rested and fed (Bessesen \& Saborío, 2012). L. olivacea was recorded at 20 sightings, representing 21 turtles. This species was only documented in the lower half of the inlet with the majority of sightings $(\mathrm{N}=12)$ taking place in GA3. A copulating pair of L. olivacea was recorded about $2 \mathrm{~km}$ off-shore from Puerto Jiménez. E. imbricata was recorded at 10 sightings, representing 10 turtles. This species 


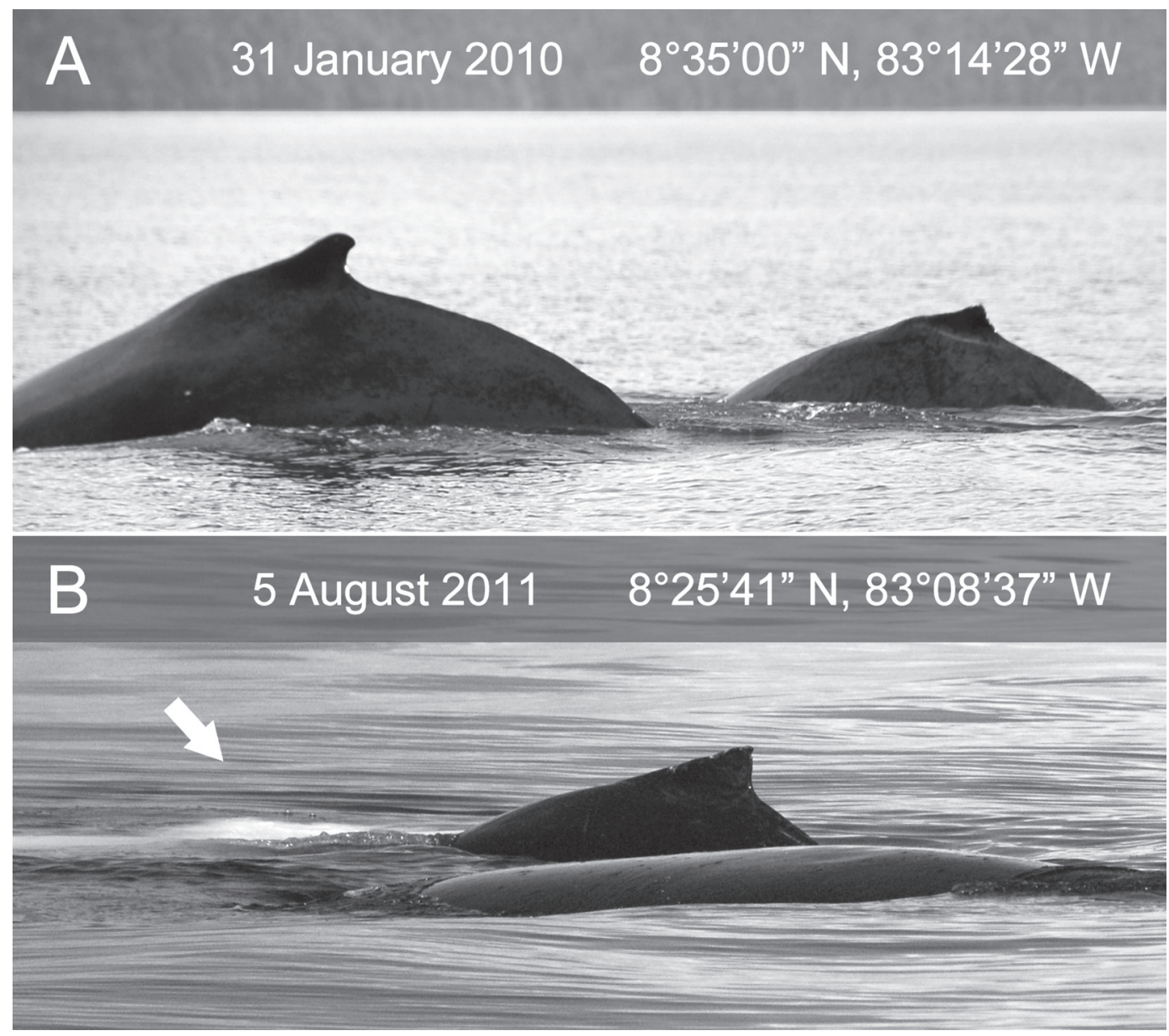

Fig. 3. M. novaeangliae mother-calf pairs inside Golfo Dulce during both dry and rainy seasons. (A) traveling in midwaters between Puerto Jiménez and Golfito, North Pacific migration period; (B) nursing behavior, milk visible in water (arrow), Southern Ocean migration period.

was seen from GA1-4, mostly ( $\mathrm{N}=9)$ along the coastal perimeter (Bessesen \& Saborío, 2012, unpublished), including one specimen in an area of mangroves described by Gaos et al. (2010) as emerging habitat for that species. $E$. imbricata was notably the smallest sized sea turtle species seen in the inlet. SEA SNAKES. Bright yellow specimens of $P$. platura of the order Squamata were recorded at 66 sightings, representing 68 sea snakes (Bessesen, 2012, unpublished). The sea snakes were typically $(99 \%)$ found floating at the surface in GA1GA2; however, one xanthic specimen was eventually recorded in GA3, just south of the inner basin sill (Fig. 1B, Table 2).

Sightings of non-focus fauna: CROCODILES. We documented two species of the order Crocodylia in Golfo Dulce. Seven specimens of Crocodylus acutus (Cuvier, 1807) were recorded at 7 sites in GA2. This species was typically found among mangrove roots in the riparian area of Rio Esquinas $(\mathrm{N}=5)$, although two were sighted along the western shores of the Gulf: one swimming in open water near Puerto Jiménez and the other found 
floating dead further to the north. Four specimens of Caiman crocodilus (Linnaeus, 1758) were seen off-survey during a nighttime kayak trip into the estuary Platanares just south of Puerto Jiménez (Fig. 1B, Table 2). SHARKS. Three species of the order Carcharhiniformes were observed inside the embayment. Galeocerdo cuvier (Peron \& Lesueur, 1822) were recorded at 2 sightings in GA2-GA2. One of those sharks appeared to be of adult size and the other was a juvenile $<1 \mathrm{~m}$ in length; each was observed swimming quietly at the water surface. Another shark sighting occurred in GA2, which was clearly a carcharhiniform, yet the species could not be confirmed. One specimen of Carcharhinus leucas (Müller \& Henle, 1839) was recorded near a riparian area in GA1. One dead juvenile S. lewini was also recorded in GA1; only the head remained, which appeared to have been severed from the body by machete (Fig. 1B, Table 2). RAYS. Four species of the order Batoidei were seen in the study area. Manta spp. was recorded at 3 sites from GA2-GA4, including one sighting of 3 individuals traveling together at the surface in a northerly direction. Aetobatus spp. was recorded at 5 sites in all areas except GA4. A group of several specimens of Rhinoptera spp. was documented over a sea grass area in GA1. Dasyatis spp. was recorded at 3 sites in or near the shallow bays of GA1 (Fig. 1B, Table 2). OTHERS. Two sightings of Pelecanus occidentalis (Linnaeus, 1766), each representing 82-150 birds, were discovered 18 months apart at the same location along the eastern shore of GA2. Both sightings took place at sunrise as the pelicans were awakening in a span of trees approximately $200 \mathrm{~m}$ in width. Tylosurus acus pacificus (Steindachner, 1876) was recorded at 1 site in GA1. This species has monthly spawning events, which take place at locally recognized spawning sites in the upper Gulf, and we made a successful trip to record an event (Fig. 1B). The remaining sightings covered an assortment of fauna, mostly fishes and invertebrates (Fig. 2).

Interviews: Of our 82 interviewees, $72 \%$ $(\mathrm{N}=59)$ were artisanal and/or tourism-sport fishermen, $13 \%(\mathrm{~N}=11)$ worked in non-fishing tourism, including boat tours and excursions, and $15 \%(\mathrm{~N}=12)$ did both. Interviewees had worked in Golfo Dulce from 1 to $40 \mathrm{yrs}$, but the average duration was $12 \mathrm{yrs}$, at an average of 5 days per week. Interview responses indicated that $96 \%(\mathrm{~N}=79)$ of those surveyed had seen whales inside Golfo Dulce, with the majority reporting the frequency as "occasionally." Interviewees generally reported whales using all four geographical areas of the Gulf, with more seen in the rainy season than the dry season. One interviewee reported witnessing a $M$. novaeangliae birth in January (dry season) 2004 in a calm bay just south of Puerto Jiménez, a location that corresponded with the neonate sighting recorded during our rainy season survey. All people interviewed reported seeing dolphins and sea turtles in the Gulf with the most common response for frequency being "always." Nesting beaches for C. mydas, L. olivacea and E. imbricata were identified along the shores of the outer basin. Five interviewees reported sightings of $D$. coriacea. Several interviewees $(\mathrm{N}=77)$ confirmed the occurrence of sea snakes in the study area, although the majority reported the species as "rarely" seen (Table 3). Consensus among interviewees described an overall decline in marine life from historical accounts. Sea turtles were reported down at least 30\%. Some large fishes, including sailfish and marlin, were no longer seen in Gulf waters. During the fishermen's associations meeting, attendees expressed serious concerns about reductions in the Golfo Dulce fisheries due to uncontrolled extraction and were advocating regulatory initiatives with the goal of increasing and stabilizing naturally occurring stocks. Nine months 
TABLE 3

Results of interviews with fishermen and tour boat guides regarding sighting frequency for target taxa

\begin{tabular}{lccccccccc}
\multicolumn{1}{c}{ Whales } & \multicolumn{2}{c}{ Dolphins } & \multicolumn{2}{c}{ Sea turtles } & \multicolumn{2}{c}{ Sea snakes } \\
\multicolumn{1}{c}{ Response options } & $\#^{1}$ & $\%^{2}$ & $\#$ & $\%$ & $\#$ & $\%$ & $\#$ & $\%$ \\
Always & 5 & 6 & 56 & 68 & 36 & 44 & 9 & 11 \\
Frequently & 10 & 12 & 23 & 28 & 33 & 40 & 17 & 21 \\
Occasionally & 42 & 51 & 3 & 4 & 10 & 12 & 15 & 18 \\
Rarely & 22 & 27 & 0 & 0 & 3 & 4 & 36 & 44 \\
Never & 3 & 4 & 0 & 0 & 0 & 0 & 5 & 6 \\
\hline
\end{tabular}

1. Number of (82) interviewees who gave that response.

2. Percentage of all interviewees who gave that response.

later, Golfo Dulce was declared a Marine Area of Responsible Fishing (La Gaceta, 2010).

\section{DISCUSSION}

Several authors have created valuable checklists of marine fauna in Golfo Dulce (Quesada-Alpízar et al., 2006; MoralesRamírez, 2011). By combining such works with ecological details for particular species and comparatively cross-referencing those details, a broader understanding of the Gulf's biotic significance may emerge. Our contribution of data should be considered from two standpoints: 1) occurrence and distribution patterns for individual orders and species, and 2) combined sighting points, which map areas of concentrated use (Fig. 1, Table 2). After distribution maps are studied, anthropogenic impacts may more clearly be evaluated, remembering that sustainability of marine resources not only supports critical fauna but also local artisanal and small-scale trade fishermen. Golfo Dulce appears to host a variety of marine life, including some endangered and critically endangered species. Although M. novaeangliae from both the North Pacific and Southern Ocean enter the inlet during seasonal aggregations in the ETP (Acevedo \& Smultea, 1995), our interview and empirical data suggest a greater number arrive from the south. It is significant that this rorqual whale was most commonly seen in mother-calf pairings. One interviewee reported observing a January humpback birth in 2004 just south of Puerto Jiménez, and a shoreline resident at the top of the Gulf reported having just witnessed the birth of a humpback calf through a telescope from her home (Shulz, pers. comm., August 21, 2011). Eye-witness accounts of births in both the dry and rainy seasons, combined with our sightings of a neonatal calf and a breastfeeding female evidence Golfo Dulce as a birthing and nursery area for M. novaeangliae from both hemispheres (Acevedo \& Smultea, 1995). Of further relevance is the distribution pattern, which shows this species most commonly utilizing the outer basin where human vessels traverse to and from the open Pacific. Félix and Haase (2001) reported a mother-calf preference for shallower waters and limited avoidance space, along with slow swim speeds and greater compulsory surface times make mother-calf pairs especially vulnerable to boat traffic (Laist, Knowlton, Mead, Collet \& Podesta, 2001; Stamation, Croft, Shaughnessy, Waples \& Briggs, 2010). Resident dolphins, $T$. truncatus and $S$. attenuata are regularly seen traveling, foraging and socializing in the Gulf. Of related ecological importance is the spawning of $T$. acus pacificus, which we observed being foraged by T. truncatus. Dolphin distribution patterns span all sectors of the embayment but group counts show the greatest numbers in GA2, where the $P$. crassidens sighting also occurred. Apex predators are said to be trophic indicators of the health of an ecosystem (Wells et al., 2004). It is therefore troubling that several T. truncatus in Golfo Dulce have lacaziosis-like disease, LLD, the first reported cases in Central America (Bessesen et al., 
2014). The disease may reflect degradation of the aquatic environment (Van Bressem, de Oliveira Santos \& de Faria-Oshima, 2009) and it is possible that waters near river outlets where bottlenose dolphins aggregate are affected by runoff of anthropogenic contaminants. Spongberg (2004) already recorded relatively high concentrations of polychlorinated biphenyls (PCBs) at $15.7 \mu \mathrm{g} / \mathrm{g} \mathrm{dw}$ sediment in the bay of Golfito. Other fundamental predators also inhabit Golfo Dulce, including two species of Crocodylia, which were found in riparian habitat and surrounding waters, and at least three species of sharks. According to the findings of López-Garro (2012), Golfo Dulce is an important nursery area for endangered $S$. lewini, evidenced by the small specimen found decapitated during our surveys. Our highest percentage of sightings $(38 \%)$ was sea turtles and, based on interviews, the offspring of at least three species emerge from nests along the shores of Golfo Dulce. Hundreds of $C$. mydas appear to utilize the Gulf year-round, resting and feeding near the inner basin and mating across all quadrants. While critically endangered Pacific D. coriacea are reported to travel into the embayment, questions of how many and for what purpose remain tantalizingly unanswered. Our numerous sightings of E. imbricata were significant since this species is also critically endangered and considerable declines have threatened imminent extirpation of the Eastern Pacific population (Gaos et al., 2010). L. olivacea appears to remain in the lower half of the embayment with the majority found in GA3. Among sea turtles, this was the only species that showed a clear variance between survey periods, being more abundant during the rainy season when mating behavior occurred. Seventeen months after our study concluded, a mass of sea turtles, at least 106, were found floating dead in the waters of Golfo Dulce. Cause of the mortalities remains undetermined but hypotheses include red tide toxity, bycatch of fishing or a combination of both (Palacios-Martínez, 2013). It is noteworthy that we photographed longlining and shrimp trawling inside Golfo Dulce during our 2011 surveys despite designation as a Marine Area of Responsible Fishing. Another remarkable finding was the colony of canary-yellow sea snakes in the inner basin (Solórzano, 2011; Bessesen, 2012). Although $P$. platura it is the most widely distributed snake species in the world (Pickwell \& Culotta, 1980), a xanthic colony has never been described elsewhere. Of the nearly 70 xanthic specimens sighted during the survey, all but one was found in the upper half of the Gulf. It has been suggested that the inner basin sill plays a role in habitat boundaries for the colony (Bessesen, 2012); however, the sighting of a xanthic specimen in GA3 near the end of our study indicates that individuals from the northern region of the Gulf do occasionally cross the sill line into the outer basin and may migrate into the Pacific population. Tu (1976) reported xanthic $P$. platura to represent $0.1 \%$ of the 3077 specimens he collected off Costa Rica. Might xanthic individuals found along Central America be "escapees" from Golfo Dulce? Preliminary phylogenetic studies show low levels of genetic divergence associated with this local variation in color pattern (Sheehy, Solórzano, Pfaller \& Lillywhite, 2012). Still, the fantastic appearance and limited range raise many exciting questions about the ecology of P. platura in Golfo Dulce. P. occidentalis can often be seen feeding in ocean waters and a year-round communal roosting site discovered along the northeastern banks of Golfo Dulce may be a key factor in the local ecology of that marine bird.

By combining all sighting points in Golfo Dulce, it is possible to distinguish biologically concentrated areas crucial for conservation. GA2 appeared to be the most vital sector of marine habitat for our target taxa, accounting for $43 \%$ of sightings of cetaceans, sea turtles and sea snakes. However, GA1 and GA3 also supported a substantial number of sightings and individuals. Because Puerto Jiménez and Golfito are positioned in midgulf where overall biodensity was highest, the anthropogenic impacts of those human communities on the marine habitat should be carefully examined. The waters near Puerto Jiménez are of particular interest as a high density area for C. mydas 
and T. truncatus, and the location of a reported birth and documented sighting of neonatal $M$. novaeangliae, copulating L. olivacea and two sharks. The estuary Platanares near Puerto Jiménez hosts a expansive and consequential array of native wildlife and may play a role in the concentrated biodiversity of the area. The whole of our findings establishes Golfo Dulce as habitat for a diverse range of vertebrates, including several flagship species of profound international interest. However, the habitat is not as vibrant or pristine as it once was. Local fishermen report observable declines in almost all marine populations and fisheries resulting from human activity. Effective management of fishing operations and enforced regulations for non-selective gear are critical to the future health of Golfo Dulce, as is the restricted growth of businesses (including touristic enterprises) that thrive on resource extraction and/ or habitat-altering development. The less-clear effects of boat traffic and anthropogenic contaminants must also be addressed. Should environmental pressures intensify, keystone species may further decline or even disappear. Moreover, as a cradle for vertebrates that migrate far beyond its borders, any ecological deterioration in Golfo Dulce may adversely affect the vitality of the broader ETP. Noninvasive research and protective strategies are essential if Golfo Dulce is to remain one of Costa Rica's true bio-gems; time must be devoted to restoring the ecosystem and acting to ensure biological treasures are not lost in the haste of development. Thus, it is hoped that scientific data will support discussions regarding new and improved measures of in situ conservation with a strong recommendation to designate this rare tropical fiord as a Marine Protected Area (MPA).

\section{ACKNOWLEDGMENTS}

This research was funded through a Greg Gund Memorial Fellowship with logistical support provided by Osa Conservation. Additional resources were provided by Osa Aventura and El Tigre Fund. My thanks to research assistant/boat captain Jorge Largaespada for his indispensable help. To Guido Saborío, Mike Boston, Adrian Forsyth, Manual Ramírez, Walter Aguirre Aguirre, Juan Diego Morales Canbronero, Marvin Villalabos Palma, Dan Hughes, Pilar Bernal, Dennis Vásquez and Yefri Amaya for support in the field. To Alberto Robleto for the kayak excursion and David Herra Miranda and Marco Loáiciga "Taboga" from CEIC for a day on their research vessel. To Jani Schulz for reporting her whale sighting. To John Calambokidis, Frank Garita, and Elizabeth Davidson for valued advice. To the anonymous reviewers for critical contributions to the manuscript. And special thanks to all the local fishermen and guides who shared their knowledge through interviews.

\section{RESUMEN}

Patrones de presencia y distribución de vertebrados marinos en el Golfo Dulce. Durante los meses de enero-febrero del 2010 y julio-agosto del 2011, se realizaron 55 muestreos de avistamientos diarios en el Golfo Dulce, una ensenada considerada un fiordo tropical en la región del Pacífico Sur de Costa Rica. El objetivo de la investigación fue recolectar datos de línea base en relación con las especies marinas que entran o residen en el Golfo, incluida la distribución espacial durante los períodos de estudio. El enfoque principal del estudio fue en especies de ballenas, delfines, tortugas marinas y serpientes marinas; sin embargo, se registraron observaciones de otras especies. Se documentaron un total de 458 avistamientos, que representan por lo menos 30 especies marinas, durante $423.7 \mathrm{~h}$ de observación en todas las áreas del Golfo. Estos datos, junto con la información obtenida a partir de 82 entrevistas a pescadores locales y guías de barcos turísticos, sugieren que una gran variedad de vertebrados marinos utilizan el Golfo con el propósito de buscar alimento, aparearse, descansar y socializar. El análisis de los datos mediante SIG permite la comparación de la distribución espacial, la cual reveló áreas de alta densidad de fauna marina en el Golfo Dulce.

Palabras clave: vertebrados marinos, distribución espacial, hábitat fiordo, Costa Rica, conservación, Pacífico Tropical Oriental.

\section{REFERENCES}

Acevedo, A., \& Smultea, M. A. (1995). First records of Humpback whales including calves at Golfo Dulce and Isa del Coco, Costa Rica, suggesting geographical overlap of northern and southern hemisphere populations. Marine Mammal Science, 11, 554-560. 
Acevedo-Gutiérrez, A., \& Burkhart, S. (1998). Seasonal distribution of bottlenose (Tursiops truncatus) and pan-tropical spotted (Stenella attenuata) dolphins (Cetacea: Delphinidae) in Golfo Dulce, Costa Rica. Revista de Biología Tropical, 46, 91-101.

Acevedo-Gutiérrez, A., Brennan, B., Rodriguez, P., \& Thomas, M. (1997). Resightings and behavior of false killer whales (Pseudorca crassidens) in Costa Rica. Marine Mammal Science, 13, 307-314.

Bessesen, B. L. (2012). Geospatial and behavioral observations of a unique xanthic colony of pelagic sea snakes, Pelamis platurus, residing in Golfo Dulce, Costa Rica. Herpetological Review, 43, 22-26.

Bessesen, B. L., \& Saborío, G. (2012). Tropical fiord habitat as a year-round resting, breeding, and feeding ground for East Pacific green sea turtles (Chelonia mydas) off Costa Rica. Herpetologival Review, 45, 539-541.

Bessesen, B. L., Oviedo, L., Hart, L. B., Herra-Miranda, D., Pacheco-Polanco, J. D., Baker, L., ... AcevedoGutiérrez, A. (2014). Lacaziosis-like disease among bottlenose dolphins Tursiops truncatus photographed in Golfo Dulce, Costa Rica. Diseases of Aquatic Organisms, 107, 173-180.

Cartwright, R., \& Sullivan, M. (2009). Behavioral ontogeny in humpback whale (Megaptera novaeangliae) calves during their residence in Hawaiian waters. Marine Mammal Science, 25, 659-680.

Cubero-Pardo, P. (2007). Distribución y condiciones ambientales asociadas al comportamiento del delfín bufeo (Tursiops truncatus) y el delfín manchado (Stenella attenuata) (Cetacea: Delphinidae) en el Golfo Dulce, Costa Rica. Revista de Biología Tropical, 55, 549-557.

Félix, F., \& Haase, B. (2001). The humpback whale off the coast of Ecuador, population parameters and behaviour. Revista de Biología Marina y Oceanografia, 36, 61-74.

Gaos, A. R., Abreu-Grobois, F. A., Alfaro-Shigueto, J., Amorocho, D., Arauz, R., Baquero, A., P., ... Zárate, P. (2010). Signs of hope in the eastern Pacific: international collaboration reveals encouraging status for the severely depleted population of hawksbill turtles Eretmochelys imbricata. Oryx, 44, 595-601.

Hebbeln, D., \& Cortés, J. (2001). Sedimentation in a tropical fiord: Golfo Dulce, Costa Rica. Geo-Marine Letters, 20, 142-148.

La Gaceta. (2010). Reglamentos: Declarar el Golfo Dulce como Área Marina para la Pesca Responsable. La Imprenta Nacional, San José, Costa Rica, 196, 33-35.

Laist, D. W., Knowlton, A. R., Mead, J. G., Collet, A. S., \& Podesta, M. (2001). Collisions between ships and whales. Marine Mammal Science, 17, 35-75.
López-Garro, A. M. (2012). Identificacion, evaluación y manejo de hábitats críticos utilizados por el tiburón martillo (Sphyrna lewini) y otros elasmobranquios en Golfo Dulce, Costa Rica (Tesis de Maestria). Universidad Nacional, Puntarenas, Costa Rica.

Morales-Ramírez, A. (2011). La diversidad marina del Golfo Dulce, Pacífico sur de Costa Rica: amenazas a su conservación. Biocenosis, 24, 9-20.

Oviedo, L. (2007). Dolphin sympatric ecology in a tropical fjord: habitat partitioning by bathymetry and topography as a strategy to coexist. Journal of the Marine Biological Association of the United Kingdom, 87, 1327-1335.

Oviedo, L., \& Solís, M. (2008). Underwater topography determines critical breeding habitat for humpback whales near Osa Peninsula, Costa Rica: implications for Marine Protected Areas. Revista de Biología Tropical, 56, 591-602.

Palacios-Martínez, G. E. (2013). Situación de la mortalidad de tortugas marinas en el Pacifico Sur de Costa Rica (Reporte de Sistema Nacional de Áreas De Conservación, Área de Conservación Osa). Puntarenas, Costa Rica: Programa Marino Costero de Acosa.

Pickwell, G. V., \& Culotta, W. A. (1980). Pelamis, P. platurus. Catalogue of American Amphibians and Reptiles, 255, 1-3.

Quesada-Alpízar, M. A., Cortés-Núñez, J., Alvarado, J. J., \& Fonseca, A. C. (2006). Características hidrográficas y biológicas de la zona marino-costera del Área de Conservación Osa. Serie Técnica: Apoyando los esfuerzos en el manejo y protección de la biodiversidad tropical. San José, Costa Rica: The Nature Conservancy.

Rasmussen, K., Palacios, D. M., Calambokidis, J., Saborío, M. T., Rosa, L. D., Secchi, E. R., ... Stone, G. S. (2007). Southern Hemisphere humpback whales wintering off Central America: insights from water temperature into the longest mammalian migration. Biology Letters, 3, 302-305.

Sheehy, C. M., Solórzano, A., Pfaller, J. B., \& Lillywhite, H. B. (2012). Preliminary Insights into the Phylogeography of the Yellow-bellied Sea Snake, Pelamis platurus. Integrative and Comparative Biology, 52, 321-330.

Solórzano, A. (2004). Snakes of Costa Rica. Santo Domingo de Heredia, Costa Rica: Instituto Nacional de Biodiversidad, INBio.

Solórzano, A. (2011). Variación de color de la serpiente marina Pelamis platura (Serpentes: Elapidae) en el Golfo Dulce, Puntarenas, Costa Rica. Cuadernos de Investigación UNED, 3, 15-22.

Spongberg, A. (2004). PCB contamination in marine sediments from Golfo Dulce, Pacific coast of Costa Rica. Revista de Biología Tropical, 52, 23-32. 
Stamation, K. A., Croft, D. B., Shaughnessy, P. D., Waples, K. A., \& Briggs, S. V. (2010), Behavioural responses of humpback whales (Megaptera novaeangliae) to whale-watching boats on the southeastern coast of Australia. Marine Mammal Science, 26, 98-122.

Svendsen, H., Rosland, R., Myking, S., Vargas, J. A., Lizano, O. G., \& Alfaro, E. J. (2006). A physicaloceanographic study of Golfo Dulce, Costa Rica. Revista de Biología Tropical, 54, 147-170.

Tu, A. T. (1976). Investigation of the sea snake, Pelamis platurus (Reptilia, Serpentes, Hydrophiidae), on the Pacific Coast of Costa Rica, Central America. Journal of Herpetology, 10, 13-18.

Van Bressem, M.F., de Oliveira Santos, M. C., \& de FariaOshima, J. E. (2009). Skin diseases in Guiana dolphins (Sotalia guianensis) from Paranagua estuary,
Brazil: a possible indicator of a compromised marine environment. Marine Environmental Research, 67, 63-68.

Wells R. S., Rhinehart, H. L., Hansen, L. J., Sweeney, J. C., Townsend, F. I., Stone, R., ... Rowles, T. K. (2004). Bottlenose Dolphins as Marine Ecosystem Sentinels: Developing a Health Monitoring System. EcoHealth, 1, 246-254.

Wolff, M., Hartman, H. J., \& Koch, V. (1996). A pilot trophic model for Golfo Dulce, a tropical fjord-like embayment, Costa Rica. Revista de Biología Tropical, 44, 215-231.

Würsig, B. \& Jefferson, R. A. (1990). Methods of photoidentification for small cetaceans. Reports of the International Whaling Commission (Special Issue), $12,42-43$. 